\title{
PENYULUHAN GIZI PADA IBU HAMIL DALAM RANGKA MEMPERINGATI HARI IBU DI KECAMATAN SAIL PEKANBARU
}

\author{
Yulrina Ardhiyanti* Liva Maita \\ STIKes HANG TUAH PEKANBARU
}

\begin{abstract}
The nutritional status of the mother before and during pregnancy can affect the growth of the fetus that is being conceived. If the mother's nutritional status is normal before and during pregnancy, it is likely that she will give birth to a healthy baby, just months at a normal weight. In other words, the quality of the baby who is born depends on the state of nutrition of the mother before and during pregnancy. The still low malnutrition of pregnant women in Indonesia continues to increase from year to year, this is what makes a study for the government to address this problem. The government continues to strive to reduce under-five and neonatal mortality by continuing to pay attention to and monitor the reduction in the prevalence of nutrition. Various efforts to improve community nutrition are carried out through activities including increasing the program of providing exclusive breastfeeding (ASI), efforts to overcome micro-nutrition through the provision of Vitamin A, Taburia, iron tablets for pregnant women, and salt iodization and management of cases of malnutrition and malnutrition. becomes a necessity for government efforts. In Sail Subdistrict, quite a number of pregnant women still lack knowledge of the nutrients needed during pregnancy. Their knowledge is only limited to the quantity of food they consume regardless of the quality of the nutrients needed during pregnancy. This is a concern of local community leaders to increase the knowledge of pregnant women to form a quality generation in commemoration of Mother's Day.
\end{abstract}

\section{Keywords : Nutrition of Pregnant Women, Education}

\begin{abstract}
ABSTRAK
Status gizi ibu sebelum dan selama hamil dapat mempengaruhi pertumbuhan janin yang sedang dikandung. Bila status gizi ibu normal pada masa sebelum dan selama hamil kemungkinan besar akan melahirkan bayi yang sehat, cukup bulan dengan berat badan normal. Dengan kata lain kualitas bayi yang dilahirkan sangat tergantung pada keadaan gizi ibu sebelum dan selama hamil. Masih rendahnya gizi buruk ibu hamil di Indonesia terus meningkat dari tahun ke tahun, ini yang membuat kajian bagi pemerintah untuk mengatasi permasalahan ini. Pemerintah terus berupaya menekan angka kematian balita maupun neonatal dengan terus memperhatikan dan memantau penurunan prevalensi gizi. Berbagai upaya perbaikan gizi masyarakat dilakukan melalui kegiatan yang mencakup peningkatan program pemberian air susu ibu (ASI) ekslusif, upaya penanggulangan gizi mikro melalui pemberian Vitamin A, Taburia, tablet besi bagi ibu hamil, dan iodisasi garam serta tata laksana kasus gizi buruk dan gizi kurang menjadi keniscayaan upaya pemerintah. Di Kecamatan Sail cukup banyak ibu hamil yang masih minim pengetahuannya tentang nutrisi yang dibutuhkan selama kehamilan. Pengetahuan mereka hanya terbatas pada kuantitas makanan yang mereka konsumsi tanpa memperhatikan kualitas dari zat gizi yang dibutuhkan selama masa kehamilan. Hal ini menjadi perhatian dari tokoh masyarakat setempat untuk meningkatkan pengetahuan para ibu hamil untuk membentuk generasi berkualitas dalam rangka memperingati hari ibu.
\end{abstract}

Kata Kunci : Gizi Ibu Hamil, Penyuluhan 


\section{Pendahuluan}

Pada kehamilan terjadi perubahan fisik dan mental yang bersifat alami, ibu harus sehat dan mempunyai kecukupan gizi sebelum dan setelah hamil. Agar kehamilan berjalan sukses, keadaan gizi ibu pada waktu konsepsi harus dalam keadaan yang baik dan selama hamil harus mendapatkan tambahan energi dan zat gizi yang seimbang untuk peertumbuhan dan perkembangan janin dengan tetap mempertahankan zat gizi ibu hamil seperti tambahan protein minimal seperti zat besi, kalsium, vitamin, asam folat dan energi (Ramayulis, 2009).

Kehamilan menyebabkan meningkatnya metabolisme energi sehingga kebutuhan energi dan zat gizi lainnya meningkat selama kehamilan. Peningkatan energi dan zat gizi tersebut diperlukan untuk pertumbuhan dan perkembangan janin, pertambahan besarnya organ kandungan, perubahan komposisi dan metabolisme tubuh ibu. Sehingga kekurangan zat gizi tertentu yang diperlukan saat hamil dapat menyebabkan janin tumbuh tidak sempurna (Nasution, 1988).

Status gizi ibu sebelum dan selama hamil dapat mempengaruhi pertumbuhan janin yang sedang dikandung. Bila status gizi ibu normal pada masa sebelum dan selama hamil kemungkinan besar akan melahirkan bayi yang sehat, cukup bulan dengan berat badan normal. Dengan kata lain kualitas bayi yang dilahirkan sangat tergantung pada keadaan gizi ibu sebelum dan selama hamil (Depkes RI, 1998).

Ibu yang mengalami kekurangan gizi pada masa kehamilan tidak hanya berdampak pada dirinya namun juga pada janin yang dikandungnya. Ibu hamil yang mengalami gizi kurang dapat mempengaruhi pertumbuhaan janin serta dapat menimbulkan keguguran, abortus, cacat bawaan dan berat badan bayi menjadi rendah (Zulhaida, 2005).

Masih rendahnya gizi buruk ibu hamil di Indonesia terus meningkat dari tahun ke tahun, ini yang membuat kajian bagi pemerintah untuk mengatasi permasalahan ini. Pemerintah terus berupaya menekan angka kematian balita maupun neonatal dengan terus memperhatikan dan memantau penurunan prevalensi gizi. Berbagai upaya perbaikan gizi masyarakat dilakukan melalui kegiatan yang mencakup peningkatan program pemberian air susu ibu (ASI) ekslusif, upaya penanggulangan gizi mikro melalui pemberian Vitamin A, Taburia, tablet besi bagi ibu hamil, dan iodisasi garam serta tata laksana kasus gizi buruk dan gizi kurang menjadi keniscayaan upaya pemerintah (Neraca, 2012). 
Oleh karena itu, perhatian terhadap gizi dan pengawasan berat badan selama hamil merupakan salah satu hal penting dalam pengawasan kesehatan pada ibu hamil. Berdasarkan permasalahan diatas, maka dirasa perlu diberikannya penyuluhan gizi pada ibu hamil.

\section{Perumusan Masalah}

Di Kecamatan Sail cukup banyak ibu hamil yang masih minim pengetahuannya tentang nutrisi yang dibutuhkan selama kehamilan. Pengetahuan mereka hanya terbatas pada kuantitas makanan yang mereka konsumsi tanpa memperhatikan kualitas dari zat gizi yang dibutuhkan selama masa kehamilan.

\section{Tujuan Kegiatan}

Tujuan kegiatan adalah meningkatkan pengetahuan masyarakat tentang gizi pada ibu hamil di Kecamatan Sail Pekanbaru.

\section{Metode Kegiatan}

Metode pengabdian kepada masyarakat yang dilaksanakan sebagai berikut :

1. Penyuluhan

Sebelum diberikan evaluasi, terlebih dahulu diberikan penyuluhan dengan tujuan agar para ibu hamil memahami tentang nutrisi yang dibutuhkan selama masa kehamilan. Dengan diberikannya penyuluhan diharapkan dapat meningkatkan pengetahuan ibu hamil serta mampu menerapkan dan memenuhi kebutuhan nutrisi yang baik yang dibutuhkan selama kehamilan .

2. Evaluasi

Setelah penyuluhan tentang gizi pada ibu hamil dilakukan, selanjutnya dilakukan evaluasi untuk mengetahui sejauh mana pemahaman yang diserap oleh ibu-ibu tersebut. Evaluasi dilakukan melalui diskusi tanya jawab tentang materi gizi pada ibu hamil yang sudah diberikan. Untuk menarik minat ibu-ibu untuk bertanya diberikan doorprize yang sudah disiapkan oleh pihak penyelenggara bekerjasama dengan masyarakat setempat. Dari hasil tanya jawab dengan para ibu-ibu diperoleh hasil bahwa sebagian besar ibu-ibu yang telah mendapatkan penyuluhan memahami tentang tentang nutrisi yang dibutuhkan selama masa kehamilan untuk kesehatan dirinya dan janin yang dikandung.

\section{Hasil}

Kegiatan penyuluhan gizi pada ibu hamil telah dilaksanakan pada hari Sabtu tanggal 24 Desember 2016 bertempat di kediaman Ibu Hj. Kelly Nulia di Jln. Satria No. 117 Kecamatan Sail Pekanbaru. Kegiatan pengabdian pada masyarakat ini memberikan hasil sebagai berikut : 
1. Ibu hamil mengetahui tentang nutrisi yang dibutuhkan selama masa kehamilan.

2. Ibu hamil mengetahui dampak yang diakibatkan oleh kurangnya pemenuhan nutrisi selama masa kehamilan pada dirinya maupun janin yang dikandungnya.

3. Ibu hamil berjanji akan menerapkan ilmu yang telah diperoleh dalam menjalani masa kehamilannya.

\section{Pembahasan}

Kegiatan penyuluhan tentang gizi pada ibu hamil yang dilaksanakan di kediaman Ibu $\mathrm{Hj}$. Kelly Nulia di Jln. Satria No. 117 Kecamatan Sail Pekanbaru berjalan dengan sangat baik. Hal ini terlihat dari antusiasnya para ibu-ibu pada saat kegiatan berlangsung. Banyaknya ibu-ibu yang bertanya menunjukkan rasa ingin tahu mereka terhadap materi yang disampaikan. Selama ini, pengetahuan mereka hanya terbatas pada pemenuhan nutrisi yang lebih banyak dibandingkan pada saat tidak hamil tanpa memperhatikan kandungan nutrisi yang dibutuhkan. Pengetahuan yang mereka miliki masih cukup rendah, diperoleh dari diskusi tentang bahan makanan yang mereka konsumsi selama hamil cenderung tidak bervariasi dan hanya ditambah jumlahnya lebih banyak. Mereka beranggapan bahwa ibu hamil lebih banyak makannya dibanding pada saat tidak hamil karena harus berbagi dengan janin. Selama ini yang mereka penuhi hanya rasa kenyang tanpa mengetahui apa-apa saja zat gizi yang dibutuhkan selama kehamilan. Tidak jarang banyak ibu-ibu yang menderita anemia pada saat hamil karena nutrisi yang mereka konsumsi tidak memenuhi kebutuhan pada saat hamil.

Kehamilan menyebabkan meningkatnya metabolisme energi sehingga kebutuhan energi dan zat gizi lainnya meningkat selama kehamilan. Peningkatan energi dan zat gizi tersebut diperlukan untuk pertumbuhan dan perkembangan janin, pertambahan besarnya organ kandungan, perubahan komposisi dan metabolisme tubuh ibu. Sehingga kekurangan zat gizi tertentu yang diperlukan saat hamil dapat menyebabkan janin tumbuh tidak sempurna. Pengetahuan atau kognitif merupakan domain yang sangat penting untuk terbentuknya tindakan seorang ibu dalam memenuhi nutrisi pada masa kehamilan. Pengetahuan dipengaruhi oleh berbagai faktor seperti pengalaman, keyakinan, fasilitas dan sosial budaya (Notoatmodjo, 2005). Sebagian besar ibu belum memahami nutrisi yang dibutuhkan selama masa kehamilan.

Menurut hasil penelitian Purbadewi \& Ulvie (2013) menyatakan bahwa Ibu 
hamil yang mempunyai pengetahuan kurang tentang anemia akan berperilaku negatif, sedangkan ibu hamil yang mempunyai pengetahuan baik akan berperilaku positif dalam hal ini adalah perilaku untuk mencegah atau mengobati anemia. Oleh karena itu, diperlukan peningkatan pengetahuan tentang anemia kepada ibu hamil. Peningkatan pengetahaun tentang anemia ini dapat dilakukan dengan cara penyuluhan yang berdasarkan karakteristiknya agar materi penyuluhan dapat diterima oleh semua ibu hamil meskipun karakteristiknya berbeda.

Oleh karena itu, untuk menghindari terjadinya kurang nutrisi pada ibu hamil salah satunya dengan memberikan pendidikan kesehatan. Diharapkan dengan bertambahnya informasi pada ibu hamil akan meningkatkan pengetahuannya yang nantinya akan berdampak terjadinya perubahan perilaku. Sehingga masalahmasalah yang terjadi pada masa kehamilan dikarenakan kurangnya asupan nutrisi dapat dikurangi yang juga berdampak terhadap penurunan Angka Kematian Ibu (AKI).

\section{Kesimpulan}

Dari kegiatan pengabdian masyarakat ini dapat disimpulkan bahwa :

1. Ibu hamil mengetahui tentang nutrisi yang dibutuhkan selama masa kehamilan.
2. Ibu hamil mengetahui dampak yang diakibatkan oleh kurangnya pemenuhan nutrisi selama masa kehamilan pada dirinya maupun janin yang dikandungnya.

\section{Saran}

Mengingat besarnya manfaat kegiatan pengabdian pada masyarakat ini, maka selanjutnya perlu :

1. Mengadakan kegiatan serupa pada tempat yang berbeda.

2. Kepada pihak puskesmas dan tokoh masyarakat, untuk mengadakan pelatihan ini pada kegiatan-kegiatan di masyarakat, seperti : arisan ataupun acara-acara lainnya.

\section{DAFTAR PUSTAKA}

Almatsier, S. (2006). Prinsip Dasar Ilmu Gizi. Jakarta : PT.Gramedia Pustaka Utama.

Depkes RI. (1992). Pedoman Pelayanan Kesehatan Prenatal di Wilayah Kerja Puskesmas. Jakarta : Direktorat Pembinaan Kesehatan Masyarakat.

Depkes RI. (1996). Pedoman Penanggulangan Ibu Hamil Kekurangan Enargi Kronis. Jakarta : Direktorat Pembinaan Kesehatan Masyarakat. 
Depkes RI. (1997). Survei Kesehatan Rumah Tangga (SKRT) 1995. Jakarta : Badan Penelitian dan Pengembangan Kesehatan.

Francin, P. (2005). Gizi Dalam Kesehatan Reproduksi. Jakarta : EGC.

Kartasapoerta, G. (2003). Ilmu Gizi. Jakarta : Rineka Cipta.

Neraca. (2012). Gizi Ibu Hamil di Indonesia Rendah, (Online), (http://www.neraca.co.id/article/1808 2/gizi-ibu-hamil-di-indonesia-rendah, diakses 20 Desember 2016).

Purbadewi, L. \& Ulvie, Y.N.S. (2013). Hubungan Tingkat Pengetahuan tentang Anemia dengan Kejadian Anemia pada Ibu Hamil, (Online), (http://jurnal.unimus.ac.id, diakses 20 Desember 2016).

Saraswati, E. (1998). Resiko Ibu Hamil Kurang Energi Kronis (KEK) dan Anemia untuk melahirkan Bayi dengan Berat Badan Lahir Rendah (BBLR). Penelitian Gizi dan Makanan jilid 21.

Sediaoetama, A. D. (2006). Ilmu Gizi. Jakarta : Dian Rakyat.

Supariasa. et.al. (2001). Penilaian Status Gizi. Jakarta : EGC. 